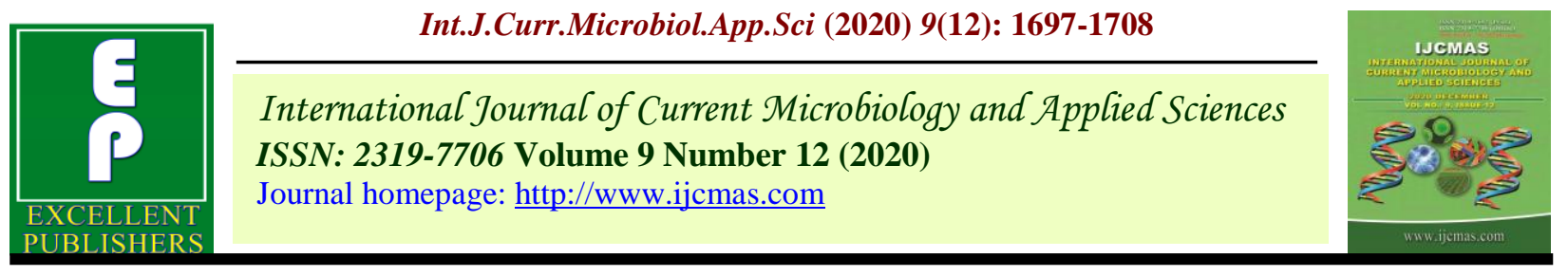

Original Research Article

https://doi.org/10.20546/ijcmas.2020.912.202

\title{
Bio-efficacy of Different Insecticides against Spodoptera litura on Groundnut
}

\author{
P.K. Waykule* , D.S. Mutkule, A.S. Jadhav, A.P. Dhormare and D.R. Bankar \\ Oilseed Research Station, Latur- 413 512, Vasantrao Naik Marathwada Krishi Vidyapeeth, \\ Parbhani (M.S.), India \\ *Corresponding author
}

\begin{abstract}
A B S T R A C T
The present field experiment were conducted to evaluate "Bio-efficacy of different insecticides against Spodoptera litura on groundnut" under field condition during Kharif season of 2019 at research farm of Oilseed Research Station, Latur, Maharashtra, India.

The observations on total number of Spodoptera litura were recorded on top, middle and bottom leaves of five randomly selected plants from each treatment at one day before and 3, 7, and 14 days after first and second application of insecticides. The treatments of different insecticides viz., Chlorantranilliprole 0.0185 per cent, Indoxacarb 0.01 per cent, Emamectin benzoate 0.002 per cent, Cypermethrin 0.002 per cent, Profenophos 0.1 per cent and Quinalphos 0.005 per cent were evaluated against Spodoptera litura revealed that among all the insecticides chlorantranilliprole 0.0185 per cent was found most effective for managing gram pod borer larvae population followed by indoxacarb 0.01 per cent, emamectin benzoate 0.002 per cent, cypermethrin 0.002 per cent, profenophos 0.1 per cent and quinalphos 0.005 per cent. Significantly higher seed yield $(3286 \mathrm{~kg} / \mathrm{ha})$ of groundnut was recorded in treatment chlorantranilliprole 0.0185 per cent however, it was found at par with treatment Indoxacarb 0.01 per cent $(3133 \mathrm{~kg} / \mathrm{ha})$. The highest ICBR (1:5.02) was recorded with treatment chlorantranilliprole 0.0185 per cent which was followed by Indoxacarb 0.01 per cent $(1: 4.91)$.
\end{abstract}

\section{Keywords}

Bio-efficacy,

Different

insecticides,

Spodoptera litura

Article Info

Accepted:

12 November 2020

Available Online:

10 December 2020

\section{Introduction}

Groundnut (Arachis hypogaea L.), is an important oilseed and ancillary food crop of the world belongs to genus Arachis tribe Aechynomenae, family Fabaceae, is a tetra foliate legume crop with yellow sessile flowers and subterranean pods. It is native of South America. It is a valuable cash crop for millions of small scale farmers in the semiarid tropics and is the principle oilseed crop in
India. The groundnut seeds are rich source of edible oil (48 to 50 per cent), protein (26 to 28 per cent) and also a valuable source of dietary fiber, minerals and vitamins namely $\mathrm{B}, \mathrm{E}$ and K (Smith, 2002) ${ }^{[33]}$. Among the total fatty acid in groundnut oil Oleic acid and linoleic acid accounts for 75 to 80 per cent of the total fatty acid in groundnut oil (Mercer et al., 1990) [23]. It is also known as 'Indian Almond' and eaten as roasted or boiled. After the oil extraction groundnut cake is a high 
protein animal feed and haulm provides quality fodder. A variety of value products like peanut butter, chikki, milk, burfi, bhujia and biscuits are made from groundnut. The groundnut shell used in industries as fuel, filler in fertilizers and in extraction of mustard facilitates better recovery and low energy consumption.

World's statistics revealed that India has the largest groundnut growing area in the world and is the second largest producer after china. Gujarat, Andhra Pradesh, Tamil Nadu, Rajasthan, Karnataka and Maharashtra are the major groundnut growing states of India and together account for about $90 \%$ of the national area under groundnut. In India, groundnut crop is cultivated in Kharif, Rabi and summer seasons grown in an area of about $5.06 \mathrm{~m}$ ha with the production of 8.05 $\mathrm{mt}$ and productivity of $1583 \mathrm{~kg} / \mathrm{ha}$. In Maharashtra, the area under groundnut cultivation was 1.95 lakh hectare with production of 2.66 lakh metric tons and productivity comprises $883 \mathrm{~kg}$ per hectare (Anonymous, 2018) ${ }^{[5]}$.

The biggest threat to groundnut cultivation is the vulnerable wide spread attack by more than 115 insects have been reported to occur on groundnut in India and few are quite destructive and reduce the yield considerably. The crop annually incurs losses amounting to Rs. 238 crores due to insect-pests and diseases (Dutta et al., 2020) ${ }^{[13]}$. Insect pests of groundnut causes damage in both field and storage conditions. Of these, Spodoptera litura, Aproaerema modicella, white grub, thrips, aphid, jassids, gram caterpillar, red hairy caterpillar and termites are found to be economically important. Possible yield losses due to Aproaerema modicella are estimated 49.56 per cent, Jassids 40 per cent, aphid 1640 per cent, thrips $17-40$ per cent, red hairy caterpillar 26-75 per cent. Tobacco caterpillar, Spodoptera litura is one of the important pest which is polyphagous and occur regularly in the field. Helicoverpa armigera and Spodoptera litura causes about 26 to $100 \%$ yield loss under field conditions (Dhiret al., 1992) [11]. Helicoverpa armigera and Spodoptera litura are reported to cause damage on more than 180 crops (Islam et al., 2007) [19]. Hairy caterpillar are widely distributed in Asia and Africa and it is polyphagous insect pest of groundnut, the larvae of hairy caterpillar, feed on groundnut leaves, buds and flowers (Rangarao and Rao, 2013) [29]. Amongst which Aproaerema modicella Deventer, Amrasca biguttula biguttula, Spodoptera litura Fabricus, Helicoverpa armigera Hubner, Aphis craccivora Koch, Scirtothrips dorsalis $\mathrm{H}$. are considered as important destructive pests on groundnut (Amin and Mohammad, 1980) ${ }^{[4]}$.

Spodoptera litura larvae feed gregariously scraping the chlorophyll soon disperse. Later stages feed voraciously on the foliage at night, hiding usually in the soil around the base of the plants during the day

\section{Materials and Methods}

The studies on "Bio-efficacy of different insecticides against Spodoptera litura on groundnut" were conducted during Kharif season 2019 at Oilseed Research Station, Latur, Maharashtra, India. The experiment was conducted in a randomized block design (RBD) with seven treatments including untreated control with three replications. Groundnut crop was sown on 31 July, 2019 in a gross plot of $4.2 \mathrm{~m} \times 5 \mathrm{~m}$ maintaining net plot of $3.6 \mathrm{~m} \mathrm{x} 4.8 \mathrm{~m}$. The row to row distance of $30 \mathrm{~cm}$ and plant to plant distance of $10 \mathrm{~cm}$ was maintained. The dose of fertilizer at the rate of $20 \mathrm{~kg} \mathrm{~N}, 40 \mathrm{~kg} \mathrm{P}_{2} \mathrm{O}_{5}$ and $40 \mathrm{~kg} \mathrm{~K}_{2} \mathrm{O}$ per hectare was given at the time of sowing. The crop was grown under protective irrigation. The treatments of different insecticides viz., Chlorantranilliprole 0.0185 
per cent, Indoxacarb 0.01 per cent, Emamectin benzoate 0.002 per cent, Cypermethrin 0.002 per cent, Profenophos 0.1 per cent and Quinalphos 0.005 per cent were applied on appearance of lepidopteran pests and subsequent spray were given at 15 days interval using manually operated knapsack sprayer. The observations on total number of Spodoptera litura larvae was recorded per five plant from each on top, middle and bottom leaves of five randomly selected plants from each treatment at one day before treatment and 3, 7, and 14 days after first and second application of insecticides.

\section{Results and Discussion}

The bio-efficacy data regarding Spodoptera litura during Kharif 2019 on groundnut.

\section{Spodoptera litura}

\section{First spray}

The effect of different insecticides on population of Spodoptera litura on groundnut after first spray are presented in Table 1 and depicted in Fig. 1. The results revealed that all the insecticides were found significantly superior over untreated control in reducing larval population of Spodoptera litura at 3, 7, and 14 days after first spray application.

At three day after first spray, significantly minimum larval population of Spodoptera litura (1.07 larvae/five plant) was recorded from the plots treated with treatment T2 i.e. Chlorantranilliprole 18.5 SC @ 0.0185 per cent. The next effective treatment was treatment T4 i.e. Indoxacarb 15.8 SC @ 0.01 per cent (3.13 Spodoptera litura larvae /five plant) which was followed by treatment T6 i.e. Emamectin benzoate 5 WDG @ 0.002 per cent (4.67 Spodoptera litura larvae/five plant) in reducing Spodoptera litura larvae population. The subsequent order of effectiveness was treatment T3 i.e. Cypermethrin 10 EC @ 0.02 per cent (5.67 Spodoptera litura larvae/five plant) and treatment T5 i.e. Profenophos 50 EC @ 0.1 per cent (6.33 Spodoptera litura larvae/five plant). These three treatments were found statistically at par with each other. The next best treatment observed was treatment T1 i.e. Quinalphos 25 EC @ 0.05 per cent which recorded 7.00 Spodoptera litura larvae/five plant. Significantly highest spodoptera population (9.67 Spodoptera litura larvae/five plant) was observed in treatment $\mathrm{T} 7$ i.e. untreated control.

At seven days after first spray the treatment T2 i.e. Chlorantraniliprole 18.5 SC 0.0185 per cent observed significantly effective in minimizing Spodoptera litura larvae population (2.40 larvae/five plant). The next effective treatment was T4 i.e. Indoxacarb 15.8 SC @ 0.01 per cent (5.60 Spodoptera litura larvae/five plant) which was followed by treatment T6 i.e. Emamectin benzoate 5 WDG @ 0.002 per cent (7.00 Spodoptera litura larvae/five plant) in reducing Spodoptera litura larvae population. Both these T4 and T6 treatments were found statistically at par with each other. The subsequent order of effectiveness was treatment T3 i.e. Cypermethrin 10 EC @ 0.02 per cent (8.33 Spodoptera litura larvae/five plant). The next effective treatment was T5 i.e. Profenophos 50 EC @ 0.1 per cent (9.00 Spodoptera litura larvae/five plant). These three treatments i.e. T6, T3 and T5 were statistically at par with each other. The subsequent order of effectiveness was treatment T1 i.e. Quinalphos 25 EC @ 0.05 per cent (10.67 Spodoptera litura larvae/five plant) and both these T5 and T1 were found statistically at par with each other. While the highest population of 14.33 Spodoptera litura larvae/five plant was recorded in treatment T7 i.e. untreated control. 
Table.1 Effect of different insecticides on the population of Spodoptera litura on groundnut (After first spray)

\begin{tabular}{|c|c|c|c|c|c|c|}
\hline \multirow[t]{3}{*}{ Tr. No. } & \multirow[t]{3}{*}{ Treatment } & \multirow{3}{*}{$\begin{array}{c}\text { Concentratio } \\
\text { n used }(\%)\end{array}$} & \multicolumn{4}{|c|}{ Mean population of Spodoptera litura larvae per five plant } \\
\hline & & & \multirow{2}{*}{$\begin{array}{c}1 \text { day before } \\
\text { Spraying }\end{array}$} & \multicolumn{3}{|c|}{ Days after spraying } \\
\hline & & & & 3 & 7 & 14 \\
\hline T1 & Quinalphos $25 \mathrm{EC}$ & 0.005 & $\begin{array}{c}16.27 \\
(4.09)^{*}\end{array}$ & $\begin{array}{c}7.00 \\
(2.73)\end{array}$ & $\begin{array}{l}10.67 \\
(3.31)\end{array}$ & $\begin{array}{l}11.67 \\
(3.46)\end{array}$ \\
\hline $\mathbf{T} 2$ & Chlorantranilliprole $18.5 \mathrm{SC}$ & 0.0185 & $\begin{array}{l}11.20 \\
(3.42)\end{array}$ & $\begin{array}{c}1.07 \\
(1.25)\end{array}$ & $\begin{array}{c}2.40 \\
(1.70)\end{array}$ & $\begin{array}{c}2.67 \\
(1.77)\end{array}$ \\
\hline T3 & Cypermethrin $10 \mathrm{EC}$ & 0.002 & $\begin{array}{l}14.13 \\
(3.81)\end{array}$ & $\begin{array}{c}5.67 \\
(2.48)\end{array}$ & $\begin{array}{c}8.33 \\
(2.97)\end{array}$ & $\begin{array}{c}9.33 \\
(3.13)\end{array}$ \\
\hline T4 & Indoxicarb $15.8 \mathrm{SC}$ & 0.02 & $\begin{array}{l}13.80 \\
(3.76)\end{array}$ & $\begin{array}{c}3.13 \\
(1.91)\end{array}$ & $\begin{array}{c}5.60 \\
(2.47)\end{array}$ & $\begin{array}{c}6.13 \\
(2.57)\end{array}$ \\
\hline T5 & Profenophos $50 \mathrm{EC}$ & 0.1 & $\begin{array}{l}15.40 \\
(3.98)\end{array}$ & $\begin{array}{c}6.33 \\
(2.61)\end{array}$ & $\begin{array}{c}9.00 \\
(3.08)\end{array}$ & $\begin{array}{c}9.47 \\
(3.16)\end{array}$ \\
\hline T6 & Emamectin benzoate 5 WDG & 0.002 & $\begin{array}{l}13.67 \\
(3.76)\end{array}$ & $\begin{array}{c}4.67 \\
(2.27)\end{array}$ & $\begin{array}{c}7.00 \\
(2.73)\end{array}$ & $\begin{array}{c}7.00 \\
(2.74)\end{array}$ \\
\hline T7 & Untreated Control & - & $\begin{array}{l}13.60 \\
(3.72)\end{array}$ & $\begin{array}{c}9.67 \\
(3.18)\end{array}$ & $\begin{array}{l}14.33 \\
(3.84)\end{array}$ & $\begin{array}{l}14.67 \\
(3.88)\end{array}$ \\
\hline & S.E. \pm & & 0.246 & 0.117 & 0.154 & 0.173 \\
\hline & C.D. at $5 \%$ & & NS & 0.356 & 0.466 & 0.526 \\
\hline & C.V. $(\%)$ & & 11.22 & 8.66 & 9.27 & 10.15 \\
\hline
\end{tabular}

*Figures in parentheses are square root $(x+0.5)$ transformed values. NS: Non significant 
Table.2 Effect of different insecticides on the larval population of Spodoptera litura on groundnut (After second spray)

\begin{tabular}{|c|c|c|c|c|c|c|}
\hline \multirow[t]{3}{*}{ Tr. No. } & \multirow[t]{3}{*}{ Treatment } & \multirow{3}{*}{$\begin{array}{c}\text { Concentratio } \\
\text { n used }(\%)\end{array}$} & \multicolumn{4}{|c|}{ Mean population of Spodoptera litura larvae per five plant } \\
\hline & & & \multirow{2}{*}{$\begin{array}{c}1 \text { day before } \\
\text { Spraying }\end{array}$} & \multicolumn{3}{|c|}{ Days after spraying } \\
\hline & & & & 3 & 7 & 14 \\
\hline T1 & Quinalphos $25 \mathrm{EC}$ & 0.005 & $\begin{array}{c}13.53 \\
(3.73)^{*}\end{array}$ & $\begin{array}{l}10.33 \\
(3.29)\end{array}$ & $\begin{array}{l}11.33 \\
(3.43)\end{array}$ & $\begin{array}{l}11.67 \\
(3.47)\end{array}$ \\
\hline $\mathbf{T 2}$ & Chlorantranilliprole $18.5 \mathrm{SC}$ & 0.0185 & $\begin{array}{l}13.20 \\
(3.70)\end{array}$ & $\begin{array}{c}1.13 \\
(1.28)\end{array}$ & $\begin{array}{c}1.60 \\
(1.44)\end{array}$ & $\begin{array}{c}2.93 \\
(1.85)\end{array}$ \\
\hline T3 & Cypermethrin $10 \mathrm{EC}$ & 0.002 & $\begin{array}{l}15.67 \\
(4.02)\end{array}$ & $\begin{array}{c}5.33 \\
(2.41)\end{array}$ & $\begin{array}{c}7.67 \\
(2.85)\end{array}$ & $\begin{array}{c}8.67 \\
(3.02)\end{array}$ \\
\hline T4 & Indoxicarb $15.8 \mathrm{SC}$ & 0.02 & $\begin{array}{l}13.87 \\
(3.78)\end{array}$ & $\begin{array}{c}3.27 \\
(1.93)\end{array}$ & $\begin{array}{c}3.73 \\
(2.05)\end{array}$ & $\begin{array}{c}5.33 \\
(2.41)\end{array}$ \\
\hline T5 & Profenophos $50 \mathrm{EC}$ & 0.1 & $\begin{array}{l}13.40 \\
(3.69)\end{array}$ & $\begin{array}{c}5.93 \\
(2.53)\end{array}$ & $\begin{array}{c}8.27 \\
(2.95)\end{array}$ & $\begin{array}{l}10.00 \\
(3.23)\end{array}$ \\
\hline T6 & Emamectin benzoate $5 \mathrm{WDG}$ & 0.002 & $\begin{array}{l}13.33 \\
(3.71)\end{array}$ & $\begin{array}{c}3.93 \\
(2.10)\end{array}$ & $\begin{array}{c}5.67 \\
(2.46)\end{array}$ & $\begin{array}{c}7.67 \\
(2.84)\end{array}$ \\
\hline T7 & Untreated Control & - & $\begin{array}{l}13.96 \\
(3.79)\end{array}$ & $\begin{array}{l}12.00 \\
(3.52)\end{array}$ & $\begin{array}{l}13.00 \\
(3.67)\end{array}$ & $\begin{array}{l}15.00 \\
(3.93)\end{array}$ \\
\hline & S.E. \pm & & 0.231 & 0.141 & 0.167 & 0.156 \\
\hline & C.D. at $5 \%$ & & NS & 0.427 & 0.506 & 0.473 \\
\hline & C.V. (\%) & & 10.59 & 10.01 & 10.73 & 9.107 \\
\hline
\end{tabular}

*Figures in parentheses are square root $(\sqrt{x+0.5})$ transformed values. NS: Non significant 
Fig.1 Effect of different insecticides on the larval population of Spodoptera litura (After first spray)

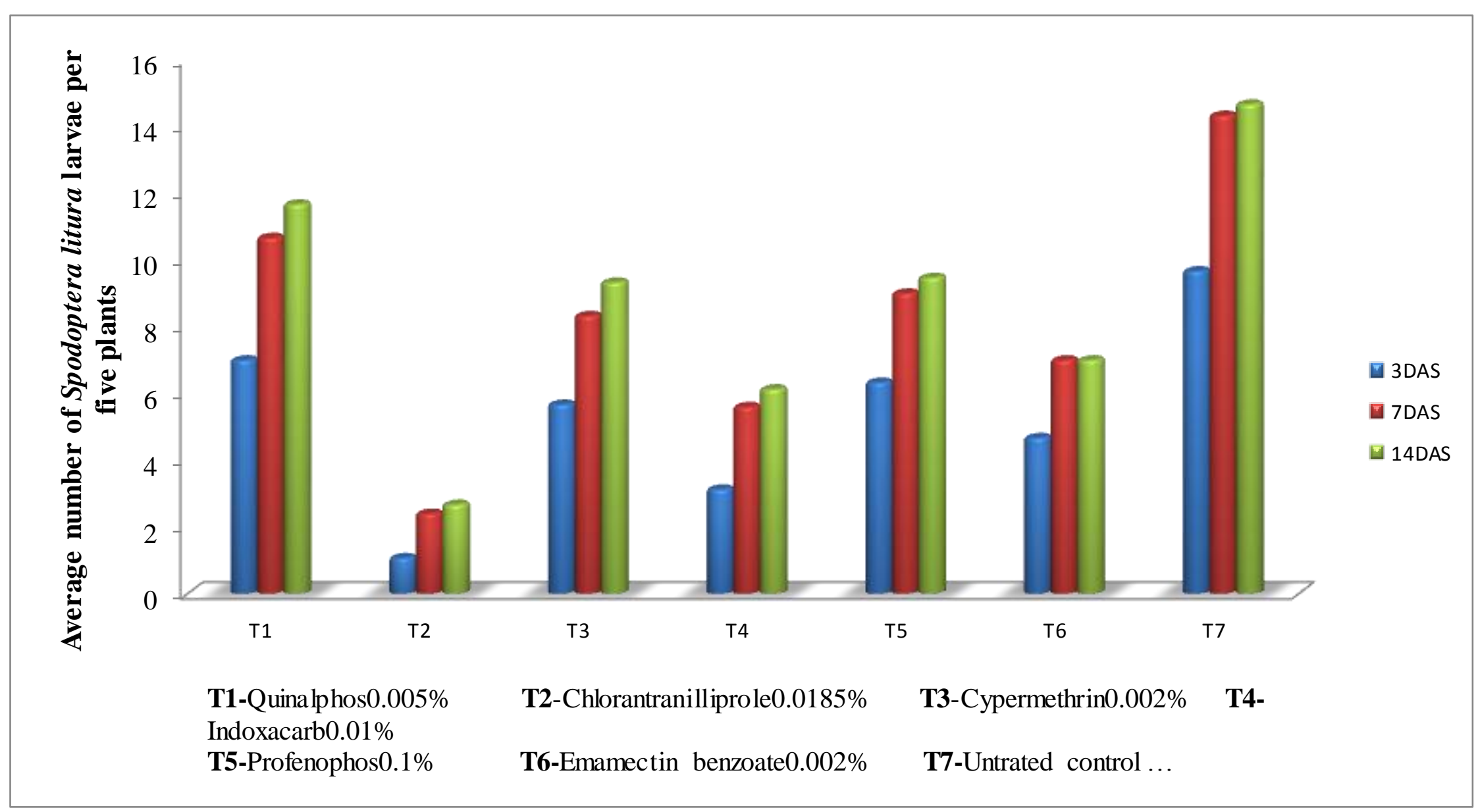


Fig.2 Effect of different insecticides on the larval population of Spodoptera litura (After second spray)

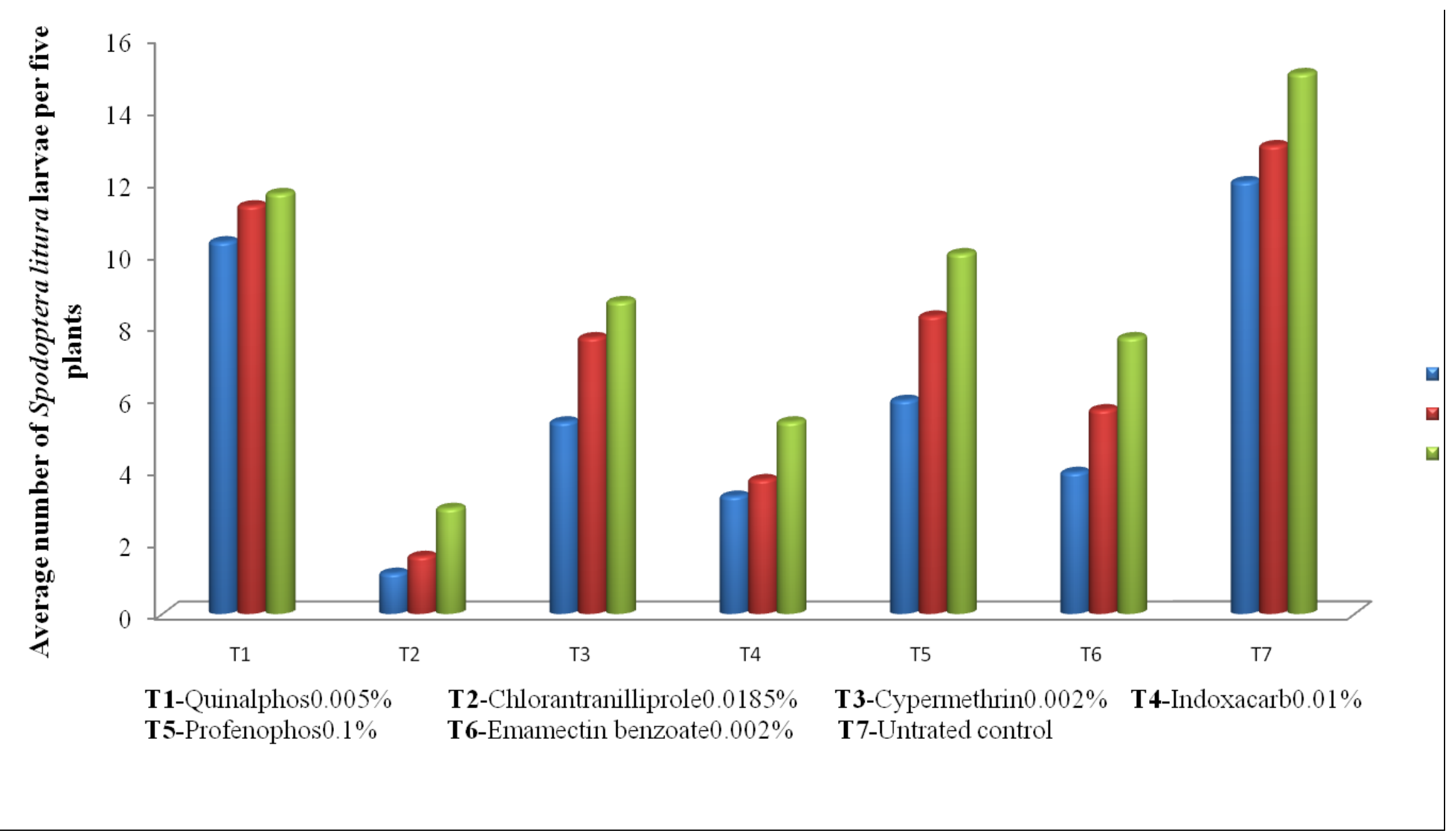


At fourteen days after first spray lowest larval population of Spodoptera litura (2.67 Spodoptera litura larvae/five plant) was recorded in the plots treated with treatment $\mathrm{T} 2$ i.e. Chlorantraniliprole 18.5 SC @ 0.0185 per cent observed significantly effective in minimizing Spodoptera litura larvae population.

The next effective treatment were treatment T4 i.e. Indoxacarb 15.8 SC @ 0.01 per cent (6.13 Spodoptera litura larvae/five plant) which was followed by treatment T6 i.e. Emamectin benzoate 5 WDG @ 0.002 per cent (7.00 Spodoptera litura larvae/five plant) in reducing Spodoptera litura larvae population. Both these treatments were found statistically at par with each other.

The next effective treatment was T3 i.e. Cypermethrin 10 EC @ 0.02 per cent (9.33 Spodoptera litura larvae/five plant) then T5 treatment i.e. Profenophos 50 EC @ 0.1 per cent (9.47 Spodoptera litura larvae/five plant). These three treatments were found statistically at par with each other. The next effective treatment was T1 i.e. Quinalphos 25 EC @ 0.05 per cent (11.67 Spodoptera litura larvae/five plant). These T3, T5 and T1 were at par with each other. The highest larval population of Spodoptera litura (14.67 larvae/five plant) was recorded in treatments T7 i.e. untreated control.

Thus, after first spray it can be concluded that the Spodoptera litura larvae population was decreased for only initial three days after first spray and thereafter the population slowly increased. Also, the plots treated with chlorantraniliprole 18.5 SC @ 0.0185 per cent recorded significantly lowest population of Spodoptera litura larvae on groundnut to the extent of $1.07,2.40$ and 2.67 larvae/plant respectively at 3,7 and 14 days after spraying and found effective over rest of the treatments.

\section{Second spray}

The results in respect of effect of different insecticides on population of Spodoptera litura larvae after second spray are presented in Table 2 and Fig. 2. The data revealed that similar trend was observed after second spray also and all the insecticides under investigation were observed to be significantly superior over untreated control in reducing the population of Spodoptera litura on groundnut at 3,7 and 14 days after second spray.

At three day after second spray, significantly minimum population of Spodoptera litura larvae (1.13 Spodoptera litura larvae/five plant) was recorded from the plots treated with treatment T2 i.e. Chlorantranilliprole 18.5 SC @ 0.0185 per cent. The next effective treatment was treatment T4 i.e. Indoxacarb 15.8 SC @ 0.01 per cent (3.27 Spodoptera litura larvae/five plant) which was followed by treatment T6 i.e. Emamectin benzoate 5 WDG @ 0.002 per cent (3.93 Spodoptera litura larvae/five plant) in reducing Spodoptera litura larvae population. Both these treatments were found statistically at par with each other. The subsequent order of effectiveness was treatment T3 i.e. Cypermethrin 10 EC @ 0.02 per cent (5.33 Spodoptera litura larvae/five plant) and treatment T5 i.e. Profenophos 50 EC @ 0.1 per cent (5.93 Spodoptera litura larvae/five plant). These three treatments were found statistically at par with each other. The next best treatment observed was treatment $\mathrm{T} 1$ i.e. Quinalphos 25 EC @ 0.05 per cent which recorded 10.33 Spodoptera litura larvae/five plant. Significantly highest Spodoptera litura larvae population (12.00 Spodoptera litura larvae/five plant) was observed in treatment T7 i.e. untreated control.

At seven days after first spray more or less same trend was observed and the treatment $\mathrm{T} 2$ 
i.e. Chlorantraniliprole 18.5 SC 0.0185 per cent observed significantly effective in minimizing Spodoptera litura larvae larvae population (1.60 larvae/five plant). The next effective treatment was $\mathrm{T} 4$ i.e. Indoxacarb 15.8 SC @ 0.01 per cent (3.73 Spodoptera litura larvae/five plant) which was followed by treatment T6 i.e. Emamectin benzoate 5 WDG @0.002 per cent (5.67 Spodoptera litura larvae/five plant) in reducing Spodoptera litura larvae population. Both these T4 and T6 treatments were found statistically at par with each other. The subsequent order of effectiveness was treatment T3 i.e. Cypermethrin 10 EC @ 0.02 per cent (7.67 Spodoptera litura larvae/five plant). The next effective treatment was T5 i.e. Profenophos 50 EC @ 0.1 per cent (8.27 Spodoptera litura larvae/five plant). These three treatments were found statistically at par with each other. The subsequent order of effectiveness was treatment T1 i.e. Quinalphos 25 EC @ 0.05 per cent (11.33 Spodoptera litura larvae/five plant). While the highest population of 13.00 Spodoptera litura larvae/five plant was recorded in treatment $\mathrm{T} 7$ i.e. untreated control.

At fourteen days after first spray, significantly lowest population of Spodoptera litura larvae (2.93 Spodoptera litura larvae/five plant) was recorded in the plots treated with treatment T2 i.e. Chlorantraniliprole 18.5 SC @ 0.0185 per cent observed significantly effective in minimum Spodoptera litura larvae population. The next effective treatment were treatment T4 i.e. Indoxacarb 15.8 SC @ 0.01 per cent (5.33 Spodoptera litura larvae/five plant) which was followed by treatment $\mathrm{T} 6$ i.e. Emamectin benzoate 5 WDG @ 0.002 per cent (7.67 Spodoptera litura larvae/five plant) in reducing larval population. Both these treatments were found statistically at par with each other. The next effective treatment was T3 i.e. Cypermethrin 10 EC @ 0.02 per cent (8.67 Spodoptera litura larvae/five plant) then
T5 treatment i.e. Profenophos 50 EC @ 0.1 per cent (10.00 Spodoptera litura/five plant). These three treatments were found statistically at par with each other. The next effective treatment was T1 i.e. Quinalphos 25 EC @ 0.05 per cent (11.67 Spodoptera litura larvae/five plant). These treatments T3, T5 and $\mathrm{T} 1$ were at par with each other. The highest population of Spodoptera litura larvae (15.00 Spodoptera litura larvae/five plant) was recorded in treatments T7 i.e. untreated control.

Thus, overall it was observed that the insecticidal treatments suppress the Spodoptera litura larvae population for initial period only. The population increased slowly after three days onwards of the spray. Also, among the insecticides tested chlorantranilliprole 18.5 SC @ 0.0185 per cent was found most effective as it recorded significantly lowest population of Spodoptera litura larvae on groundnut to the extent of $1.13,1.60$ and 2.93 larvae per plant at 3, 7 and 14 days after spraying, respectively over rest of the insecticides.

Earlier, the effectiveness of chlorantranilliprole against Spodoptera litura on groundnut was reported by Gadhiya et al., (2014) ${ }^{[15]}$.The effectiveness of chlorantranilliprole as foliar spray against defoliators on castor by Duraimurugan and Laxminarayana (2014) ${ }^{[12]}$. Among four insecticides they concluded chlorantranilliprole @ $30 \mathrm{~g}$ a.i. per ha were very effective in suppressing the larval population of semilooper and tobacco caterpillar (Spodoptera litura). Gadhiya et al., (2014) ${ }^{[15]}$ reported chlorantranilliprole and emamectin benzoate most effective and chlorantranilliprole followed by indoxacarb to control Spodoptera litura infesting groundnut. Kumar et al., (2015) [21] monitored bioefficacy of nine insecticides against Spodoptera litura on groundnut and reported 
chlorantranilliprole found most effective. Muzammilet al., (2017) ${ }^{[27]}$ on sunflower against defoliators. Chopade et al., (2018) ${ }^{\text {[9] }}$ studied newer insecticides against major insect pests of sesamum and reported chlorantranilliprole were most effective against capsule borer.

The next effective treatment were indoxacarb Harish et al., (2009) ${ }^{[18]}$ reported emamectin benzoate superior to chloropyriphos against lepidopteran defoliator in soyabean. Mutkule et al., (2009) [26] evaluated spinosad and emamectin benzoate found best in suppression of larval population against Spodoptera litura on groundnut. Emamectin benzoate + novaluron reduce larval population of Spodoptera litura on groundnut reported by Satynararayana et al., (2010) ${ }^{[30]}$. Bhandane et al., (2016) [7] reported emamectin benzoate and cypermethrin more effective against Spodoptera litura on castor. But the present study investigated that chlorantranilliprole most effective followed by indoxacarb and emamectin benzoate.

The present study concluded that among the seven treatments, all the insecticide treatments were more effective than control in reducing the Spodoptera litura larvae chlorantranilliprole 0.0185 per cent was found extremely effective for control of larval population of Spodoptera litura on groundnut.

\section{References}

1. Aghav ST, Bhandane RS, Sushir MA, Patil AJ, Dharme PK. Evaluation of methomyl 40 SP against Spodoptera litura fab. infesting groundnut. Pestology 2007; 21(12): 27-28.

2. Agricultural and Processed Food Product Export Development (APEDA) ministry of commerce and industry, Government of India, Kharif 2018, Survey of Groundnut Crop.
3. Amin PW. Resistance of wild species of groundnut to insect and mite pests. Proceedings of groundnut to insect and mite pests. Proceedings of an international workshop on cytogenetics of Arachis, ICRISAT Center, Patancheru, India 1985; 57-60.

4. Amin PW, Mohammad. Groundnut pest research at ICRISAT. Proceedings of the International Workshop on Groundnut, ICRISAT Center, Patancheru, A. P., India 1980; pp.158166.

5. Anonymous. Rabi/Summer groundnut Workshop, Progress Report, Project coordinating unit, Groundnut, National Research Centre for Groundnut , Junagadh 2018; pp. 20-34.

6. Ayyanna $\mathrm{T}$, Arjunrao $\mathrm{P}$, Subbaratnam GV, Rao BHKM, Narayana, KL. Chemical control of Spodoptera litura Fabricius on groundnut crop. Pesticides 1982; 16(8): 19-20.

7. Bhadane M, Kumar NN, Acharya MF. Bioefficacy of modern insecticides against Spodoptera litura Fabricius on castor. Int. J.Agric. Inn. Res 2016; 4(4):789-795.

8. Biradar Renuka, Hegde Mahabaleshwar. Management of insect pests on rabi/summer groundnut. J. Expect. Zool. India 2016; 19(1): 527-529.

9. Chopade BJ, Rathod PK, Chaudhari RH, Bharatkumar GS, Golvankar GM. Efficacy of newer insecticides against major insect pests of sesamum. Int. J. Chemical Studies 2018;6(5):2249-2252.

10. Dharne PK, Patil SK, Patil RB. Field evaluation of some insecticides against Spodoptera litura Fabricius on groundnut. J. Maharashtra Agric. Uni 2001; 26(2): 164-165.

11. Dhir BC, Mohapatra HK, Senapati B. Assessment of crop loss in groundnut due to Spodoptera litura (F.). Indian J. Plant protect 1992; 20: 215-217. 
12. Duraimurugan $\mathrm{P}$, Lakshminarayana $\mathrm{M}$. Efficacy of newer insecticides against defoliators and capsule borer in castor. Indian J. of Plant Protection 2014; 42(4): 307-311.

13. Dutta D, Banddopadhyay P. Production potential of intercropping of groundnut (Arachis hypogea) with pigeonpea (Cajanus cajan) and maize under various proportions in rainfed. Indian $\mathbf{J}$. of Agronomy 2006; 51(2): 103-106.

14. Dwivedi SL, Reddy DVR, Nigam SN, Rao GVR, Wightman JA, Amin PW, Nagabhaushanam GVS, Reddy AS, Scholberg E, Ramraj VM. Registration of ICGV 86031 peanut genotype. Crop science 1993; 33(1): 220;4 ref.

15. Gadhiya HA, Borad PK, Bhut JB. Effectiveness of synthetic insecticides against Helicoverpa armigera hardwick and Spodoptera litura infesting groundnut. An International Quarterly Journal Of Life Sciences 2014;9(1):2326.

16. Ghevande MP, Nandgopal V. Integrated pest management in groundnut in India. Integrated Pest Management Reviews 1997; 21-15.

17. Gomez KA, Gomez, AA. Statistical procedures for agricultural research. John wiley and sons, New York 1984;p680.

18. Harish G, Patil RH, Giraddi RS. Evaluation of biorational pesticides against lepidopteran defoliators in soybean. Karnataka J. Agric. Sci 2009; 22(4): 914-917.

19. Islam MB, Machial CM, Miresmaill S, Bainyard LD. Essential oil based pesticides: new insights from old chemistry. In: Pesticide chemistry, $\mathrm{H}$. Ohkawa and H. Migayava, (Eds): Wiley. Weinheim 2007; pp.113.

20. Jayewar NE, Patait DD, Khandare RY. Chemical alternatives for management of defoliating pests of groundnut.
International Journal of Chemical Studies 2018; 6 (6): 2339-2341.

21. Kumar NK, Aacharya MF, Srinivasulu DV, Sudarshan P. Bioefficacy of modern insecticides against Spodoptera litura F. on groundnut. International Journal of Agriculture Innovations and Research 2015; 4(3): 2319-1473.

22. Mahapatra HK, Dhir BC, Senapati B, Mishra BK. Evaluation of various insecticides against Spodoptera litura F. on groundnut seedlings. Curr. Agric. Res 1995; 8(2): 79-81.

23. Mercer LC, Wynne JC, Young CT. Inheritance of fatty acid content in peanut oil, Peanut Science 1990;17(1),17-2.

24. Murthy S, Thippaiah M, Kitturmmath MS. Effect of neem formulations on larvae of tobacco cutworm, Spodoptera litura (F). Insect Environment 2006; 12: 84-85.

25. Mutkule DS, Patil PB, Jayewar NE. Management of major insects-pests of groundnut through some newer insecticides. Int. J. Current. Microbiol. App. Science 2018; 6: 281-288.

26. Mutkule DS, Patil BV, Aglave BN, Jagtap PK. Field evaluation of new molecules for the control of $S$. litura $\mathrm{F}$. on post rainy season groundnut. Indian J. Ent 2009; 71(4): 292-295.

27. Muzammil S, Biradar AP, Shruthi N. Bio-efficacy of new molecules and biorationals in the management of defoliator pests of sunflower. J. Entomol. Zool. Studies 2017; 5(5): 1561-1565.

28. Patil RK, Shekharappa. Management of Spodoptera litura Fab. On groundnut with new newer insecticides, Pestology 2002; 26(1): 23-24.

29. Rangarao GV, Rao RV. Handbook on Groundnut Insects Pests Identification and Management. Information Bulletin No. 39, Patancheru, Andhra Pradesh 502 
324, India: International Crops Research Institute for Semi-Arid Tropics 2013;88p.

30. Satyanarayanan NVV, Rao GR, Rao PA. Incidence and management of Spodoptera litura (Fab.) on post rainy season groundnut. Ann. Pl. Prot. Sci 2010; 18(1): 22-25.

31. Singh AK, Paras Nath. Insecticidal management of Spodoptera litura Fabrius infesting groundnut. Shashpa
1998;5:203-206.

32. Singh KN, Sachan GC. Assessment of yield loss due to insect pests at different growth stages of groundnut in Pantnagar, Uttar Pradesh, India. Crop Protection 1992; 1(5): 414-418.

33. Smith AF. Peanuts: the illustrious history of the goober pea. Chicago University of Illinois Press, Illinoids 2002.

\section{How to cite this article:}

Waykule, P.K., D.S. Mutkule, A.S. Jadhav, A.P. Dhormare and Bankar, D.R. 2020. Bioefficacy of Different Insecticides against Spodoptera litura on Groundnut. Int.J.Curr.Microbiol.App.Sci. 9(12): 1697-1708. doi: https://doi.org/10.20546/ijcmas.2020.912.202 